\title{
HISTORICAL INFORMATION OF ILLEGAL WRITINGS BEFORE THE EMERGENCE OF TRADITIONAL GRAFFITI
}

\author{
Simeon Zhelev \\ simeonjivkovjelev@abv.bg
}

Department of Graphic Design and Visual Communication, Veliko Turnovo University "St. St. Cyril and Methodius", Bulgaria

\begin{abstract}
With its long history, graffiti varies between very simple written words and exteemly complex wall paintings. We can find examples of these in ancient times all over the world. Some scholars assume cave paintings as examples of graffiti in their most general defini-tion. Other think that samples of graffiti can be find in ancient Pompei and later in the Middle Ages on the exterior walls of churches and cathedrals. As Kaleb Neelon says, since there were people and walls, there was someone who wrote on them.
\end{abstract}

Keywords: Graffiti; Ancient Graffiti; Pompei; Writings; Hobo Writings; Brassai; Kilroy; Latrinaria; Cholo

\section{ИСТОРИЧЕСКИ СВЕАЕНИЯ ЗА НЕОФИЦИААНИ НААПИСИ ПРЕАИ ВЪЗНИКВАНЕТО НА СЪВРЕМЕННИТЕ ГРАФИТИ}

\author{
Симеон Желев
}

КатеАра "Графричен Аизайн и визуални комуникации при "Великотьрновски университет „Св. Св. Кирил и Методий", България

Резюме: Със своята Аълга история, графритите варират межАу просто изписани Ауми Ао сложни стенни картини. Примери за тях могат Аа бъАат открити още в Аревността по целия свят. Някои учени Аори Аопускат, че пещерните рисунки са примери за графити в най-общата им Аефриниция. Аруги смятат, че примери за графоити има в Аревен Помпей, а по-късно през среАновековието, по екстериорните стени на цьркви и катеАрали. Както казва Калеб Нийлон, откакто е имало хора и стени, е имало и кой Аа пише върху тях.

КАючови Ауми: графоити; Аревни графоити; Помпей; налписи; Хобо налписи; Брасай; Кимрой; Аатринария; Чоло

Графитите варират межАу просто изписани Ауми Ао сложни стенни картини, като имат много дьлга история. Примери за тях могат да бъдат открити още в древността по целия свят. Някои учени дори смятат, че пещерните рисунки са древни примери за графрити в най- 
общата им дефиниция. Както казва Калеб Нийлон, откакто е имало хора и стени, е имало и кой $а$ пише вьрху тях.

В настоящия Аок^ал преАставям няколко интересни примера за неофициални налписи, които се наблюАават през различни историчесни периоди преди възникването на модерните графрити в края на 60-те години в Ню Йорк и Филалелффия.

\section{Исторически свеАения}

От глеАна точка на запалната цивилизация, Аревните графрити са разпространени повсеместно по цялото средиземноморие. Те датират от изнамирането на писмеността $А$ края на античността. Появяват се на най-различни места: в градовете и техните околности, на религиозни места, в екстериора и интериора на къщи, на публични пространства и т.н. Те се издраскват, издьлбават, изстьргват върху стени, колони и Аруги архитектурни елементи, както И върху поАвижни обекти като керамични съдове. Вк^ючват различни текстове, картини, пиктограми и символи. ЕАни от Аобре запазените примери за Аревни графити в гралска среАа могат $А$ а се открият в античните гралове Помпей и Херкулан в Италия (затрупани от вулканично изригване), АураЕвропос в Сирия и грьцките гралове Еорес, Смирна (Измир), Афрродизиас, намиращи се в Анешна Турция, както и издраскани текстове върху каменни стени в древен Египет.

Прелполага се, че голяма част от Аревните графиити не оцелеляват Ао Анешно време, тьй като голям процент от налписите се откриват на места, които по еАин или Аруг начин успяват $\Delta а$ се запазят много добре през годините. От гледна точка на тяхното съзАаване те могат $\Delta$ व се разделят на $\Delta в$ б типа графити, елните са на принципа на отнемане от материала, най-често издраскване и издьлбаване с някакъв остьр инструмент, а другия тип е с добавянето на материал, най-често изписване с боя, туш или въглен (Baird and Taylor, 2016: pp. 1718). 


\section{Прихики и разлики межАу съвременни и Аревни}

\section{графити}

Разбира се по определени критерии Авата вида графрити имат големи разминавания, но по Аруги си приличат много. При съвременните графити се забелязва нетьрпимостта на властта към тях, като някои хора го приемат за криминално поведение, а Аруги като социално послание и изкуство. Те често се приемат като субкултурен отговор срещу статуквото. Аруги смятат графитите като начин на изразяване или критика към властта. Политическите органи най-често ги криминализират и не толерират тяхното „производство“, като Аори има моменти в историята, в които властта обявява война на графитите. За разлика от тях при древните графоити няма Аоказателства за гонения и наказания на хора драскащи по стените. Много от налписите се наблюАават в къщи и Аруг тип сгради, често изписани от собственика или изработени с неговото "мьлчаливо разбиране“. Разбира се вижАането за имущество е съвсем различно. Собствености от рода на съдове, роби, животни и т.н. са по-важни, отколкото някаква стена. Често са срещани и Аревни графрити подкрепящи вАастта и^и пьк полкрепящи Аичности участващи в игри. Така по този начин трудно бихме ги съпоставили със съвременните графрити, които както Ажефрри Рос казва са "субкултурната реакция срещу Аоминиращите власт имащи структури“" (Baird and Taylor, 2016: p. 20), (Ross, 2016).

Спорел Аж. БейрА и Клер Тейльр (Baird and Taylor, 2016) древните графоити не са проблем на правото, който трябва $а$ б бье решен, нито проблем на естетиката Аали са изкуство или не. Те поскоро са пример на неформални улични налписи говорещи на найразлични, често съперничещи се теми и загрижености.

Аревните графрити могат $\Delta$ a ce забележат на всевьзможни места. Освен в населените места (Съвременните графрити са концентрирани преАимно в гралски пространства), те се забелязват и в отАалечени региони, като временни местообитания, в отАалечени пустини, Аалечни п^анински региони обитавани от номаАски п^емена, монаси, странници и пьтешественици. 
Това е признак за тяхната функция за комуникация, както и знак за човешко присъствие. Наличие на Аревни графрити се наблюАава и по стените на ранните християнски катакомби, среАновековните цьркви и ранните модерни къщи. Очевинно е, че съвременните графоити се развиват в Аруга естетическа посока и различен стил, но и Анес съществуват издраскани налписи по Аьрвета, стени и тоалетни и т.н., посветени на схолна тематика като Аревните графрити: политически, забавни, молби и желания, религиозни и митични, Аруги са нелепи (Аични имена, прости калкулации или смешни комбинации от Ауми), някои са със смислено и Аьлбоко значение, Аруги са картинни преАставящи животни и обекти. При много от тях се забелязва комуникация межАу налписите, може $\Delta$ а е позАрав от еАин човек към Аруг, може $\Delta а$ е сатирично насочено към четящия, а в последствие, четящия да отвьрне със сатиричен отговор и т.н. Това показва, че за няКОАКО ХИ^яАИ гоАИНИ в Същината си оставаме еАни И Същи.

Както посочват $\Delta ж$. БейрА и Клер Тей^ьр, „Аревните графрити са енна от многото форми на писане, които понякога се използват за декоративна цел, а понякога и символично." (Baird and Taylor, 2016: р. 21 ). В контекста на историческото време те са още енна много $е$ есн и Аостьпна п^ощ върху, която може $а$ а се напише или изрисува нещо от грамотните (Аори и от неграмотните, чрез символи) върху стената или пола. На много места по среАиземноморието няма нужАа от специални инструменти, за $\Delta а$ напишеш нещо, трябва ти само остьр предмет, с който $\Delta а$ се издраска повьрхността. Аокато папируса, пергамента и глинените плочки не са евтин вариант за писане и не са достьпни през цялото време.

\section{Помпей}

Порали изригването на вулкана Везувий през 79 г. сл.хр., античния граА Помпей и околностите му са погребани поА отломките почти моментално.

Но благодарение на това се запазва архитектурата, вкАЮчитеАно И много от наАписите по стените на оградите и къщите (фииг.1, ффиг.2). Много от налписите са на публични и частни места: 
политически обещания, поеми, сметки, реклами, мични бележки, записки за дьлгове и т.н. Според Кристина Милньр (Kristina Milnor), Аумата "графити" започва $\Delta$ а се използва към края на XVIII век и началото на XIX век, когато посетители на античния граА Помпей, започват $\Delta$ а се обръщат към налписите вьрху стените с Аумата графити (Lewisohn, 2008: p. 26).

Разбира се тези налписи са непокътнати векове наред и никой не проявява интерес към тях, но по него време става отново модерно изследването на античната история. За тези налписи се говори като продукт на чистият порив за сьздаване. В послеАствие към края на XIX век, тези графрити започват $а$ а добиват по-негативен смисъл и се свързват с по-ниските съсловия на обществото (Lewisohn, 2008: p. 26).

Графитите в Помпей са налписи на всякаква тематика от ^юбовни откровения, политически ^озунги/обещания $А$ комерсиални графитии (сметки, менюта и реклами в някои магазини и пекарни). Някои налписи показват цените в бардаците и кръчмите, Аруги представят политическа пропаганда за някои политик, а трети: ^юбовните терзания на някой нещастно влюбен. Тези налписи Аори се наблюдават като "Аекорация" в някои Аомове. Графитите в Помпей могат $\Delta$ a се разделят в $\Delta в е$ категории: издраскани и изписани с боя. Кристина Милнър в книгата си „Графитите и митературния пейзаж в римския Помпей" определя Аревните графити като ^ично изпьлнените, публично четими текстове, намерени по стените на Помпей (Milnor, 2014: p. 4).

Античните графити затихват и се появяват отново през средновековието, преАимно върху стени на цьркви и катеАрали. Сильр Аюисън споделя, че примери за графити има през цялото ново време

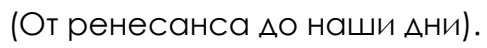

Но през XIX век публичното мнение започва $\Delta$ а приема негативно графритите, тьй като се свьрзват с работническата к^аса и се смятат за нейн проАукт, Аокато елитьт, който Аоминира културните събития се настройва срещу тях. През викторианската епоха хората се обръщат към висшето изкуство и обръщат глава от изкуството произвелено на улицата (Lewisohn, 2008: р. 27). По Българските земи 
примери за средновековни графоити могат $\Delta$ а се наблюАават по стените на повечето цьркви от съответния времеви периол. Несебър, както и по стените на цьрквите „Св. Георги” в Старо Нагоричино, „Св. Аимитьр" в Прилеп, Св. Пантелеймон" в Нерези, "Св. Архангел Михаи^” в Аесновския манастир, охрилските цьркви "Св. Софрия" И „Св. Богородица Перивлепта" и много Аруги, могат да бъдат открити Аобре запазени издраскани налписи по външните и вътрешните стени на сградите.

\section{Йозеф Киселак}

За наченки на съвременни графрити може $а$ а говорим още през XIX век. Според Крис Гантер (Chris Ganter) (Ganter, 2013: р. 12) пьрвият графити артист, който поставя своя таг на всевъзможни места и Аобивайки широка известност среА обществото е Йозефо Киселак (Josef Kyselak). Изпо^звайки четка и боя, той поставя името си, често придружено с датата на изписване, на множество публични места, имперски сграли и религиозни храмове във Виена и на места от Австрийската империя (фриг.3, фриг.4). Неговите „тагове“ го правят толкова известен, че дори императорьт го привиква със съвет $а$ а спре с полписите си.

\section{Хобо графити.}

Признаци на съвременни графити се забелязват още през 30-те голини на 20 век в САЩ, както и по тьмните улици на Париж. В Щатите, хобо графитите са еАни от най-ранните нелегални налписи по стени, влакове и обществени сгради.

А в Париж, Гю^а Ха^аз, познат като Брасай, прави фротографрии на графити, като повечето от тях са Аоста примитивни и Аетски, но според него, сьльржащи голяма енергия и свобола, каквато не би могла $\Delta$ a се постигне от „сериозните“ артисти (Lewisohn, 2008: р. 29).

Хобо или скитници са хората странстващи из страната, търсейки временна работа, като преАставят най-ниското стьпало от икономиката на САЩ (фриг. 5). Това се случва към края на XIX век и началото на XX век, като пиковите цифри на скитащите работници 
съвпала с икономическите кризи в щатите (голямата Аепресия). Разрастващата се железопьтна мрежа, както и лесното нелегално качване в пьтуващите товарни влакове в страната, спомага за тяхното по-^есно приАвижване, както и условия Аа си намерят по-лесно работа, тъй като в много от случаите тя е временна. Въпреки лесния транспорт, нелегалното пьтуване във влаковете крие опасности. Вероятността $а$ а бъ $\Delta$ е хванат $\Delta$ ален странстващ работник е голяма, и той може $\Delta а$ бъ $\Delta е$ изхвьрлен от охраната повреме на Авижение на влака. Затова хобо налписите играят голямо значение и служат като инструмент за комуникация. Те имат практическа и символична стойност.

Хобо графитите се появят по обекти близо Ао железопьтни АИниИ, като воАни кули, поАлези и мостове (фриг. 6), а от там по-късно преминават и по вагоните на влаковете, пьтуващи из цялата страна. Много от тях са изображения или полписи на конретен човек, който заявява своето присъствие, както и че е обитавал временно вагон. Тези налписи, силно наподобяващи йероглифи, имат свой характерен език с прости заколирани сьобщения, които могат Аа бъдат разбрани само от членовете на тази субкултура, най-често те са дати, прякори, знаци^ога, препорьки, указания и т.н. (фиг. 7) Относно хобо графиитите има множество легенди, както и изписани томове митература и статии от вестници, но много трудно може $А$ व се Аокаже $а$ али са реални или $А$ а се установи точна терминология, тъй като много от тях са написани от членове на тази субкултура, като в много от случаите истината не е представена обективно.

Въпреки това има еАно общоприето твърАение за хобо графритите и то е, че скитниците използват графоични знаци представящи тяхната персона, наречени още „прозвище“ (moniker) (Lowndes, 2018), които най-често показват, че макар и за кратко, са обитавали място във в^ака, т.е. графрити от сорта "Ажо беше тук“(фоиг. 8). Обикновено прозвището говори нещо за личността: от кьле е, кога е роден, някаква фризическа черта, дали е млал или стар и т.н. Аруга често срещана черта при хобо графитите е използването на Аати, съкращения и стрелки, които показват на къАе и кога пьтуват скитниците. 
Интересното е, че скитащите работници, не са единствените, които правят такъв тип графити по влаковете. Работниците към железопьтните компании, които Аьлго време остават на работа на елна и съща гара за влакове, започват да маркират преминаващи влакове с тяхно собствено прозвище.

Също като традиционните графрити в Ню Йорк, хобо графитите показват присьствието на определена група хора. При съвременните графитии пространството, което те заемат се намира предимно в градски условия, Аокато хобо графритите могат $А$ с се наблюАават в цялата страна, Аори може на целия континент, в зависимост от крайните точки на влака (Канала, Мексико).

По подобен начин на нюйоркските графити, хобо графитите се извършват нелегално, поставяйки се върху чужАа собственост, служейки за комуникация межлу членовете на субкултурата, както и заявка за иАентичност, но възникнали няколко десетилетия по-рано.

\section{Брасай}

Най-Аобре познат със фото сериите си „Нощен Париж“, както и с фотографиите на висшето общество в Париж, унгаро-фрренският фотограф Брасай (Гю^а Халаз) заснема и на еАни от ранните примери на графити в Европа през XX век. За повече от $\Delta в е$ Аесетилетия (1933-1956) той Аокументира множество издраскани, изАьлбани и изписани изображения върху стени в Париж.

Някои от тях са налписи, човешки Аица, животни, сърца, а Аруги са изцяло абстрактни (фоиг. 9, 10, 11). Благодарение на него и ^юбовта му към фротографрията, парижанските графрити Аостигат $\Delta$ по-широк кръг от хора, като през 1933 публикува част от снимките в списанието Минотавьрьт (Le Minotaure), а през 1961г. издава фоотокнигата Графрити

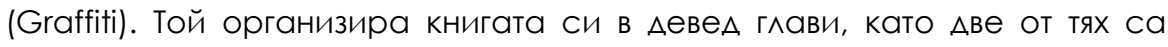
посветени на медиума и практикуването на графритите: езика на стената и твьрления за стената (The language of the wall, Propositions of the wall).

СпореА Брасай този тип графити или както той сполеля този "вандализьм" не може $\Delta а$ се обясни единствено с нуждата от 
разрушаване. Той приема издьлбаните налписи, сърцата и ююбовните послания, изтьрганите Аати, като еАин инстинкт за оцеляване, опит за увековечаване на тези, които не могат $а$ а построят пирамили или катедрали, но могат $\Delta а$ направят грасрити по стените. Това е техният начин Аа оставят името си за потомството'.

Фотографиите на Брасай окуражават зрителите Аа погледнат графритите и изкуството на улицата през друга гледна точка. Илеята, че изкуството се намира навьн в града, на най-неочаквани места, е също толкова интригуваща, колкото И съвременните тенАенции в артистичните срели, и е все така раликална и Анес. Брасай сьздава паралел межАу графитите и изкуството, той ни показва модерно примитивно изкуство, което можем да наблюдаваме по улиците на Париж, стига да сме Аостатьчно наблюАателни (Lewisohn, 2008: p. 30).

\section{Кимрой}

Много от хората свьрзват модерните графити, заедно с пьрвия известен драскач Такі 183, който „обстрелва“ с маркера си цял Ню Йорк, като става еАин от най-влиятелните хора в графиити културата. Но всьщност гоАини преАи него се появява еАин израз, който залива Щатите и Европа: Киярой беше тук (Killroy was here). Налписьт „Киярой беше тук" е често срещан по време на кьсните години на Втората световна война, когато СъеАинените щати се включват, като през 50-те години на 20 век се преврьща в нещо като ^удост, с появата му на всевьзможни места (фриг. 12, фриг. 13). Всъщност, кьАето е би^а американската армия там е можело да се срещне този налпис, приАружен с плешиво човече наАничащо с изкочи^ нос заА стена. За противниковите сили може $\Delta$ а се каже, че е изглежАало зап^ашително, но за американските войници е по-скоро нещо като морален т^асък и символ на патриотизьм. „Ки^рой е бил навсякьАе, супергерой, пазител, крьжащ около американските войници" 2 , той Ао такава степен става

1 Artazoi, [http://www.artazoi.com/portfolio/circonstances-attenuantes/, (Last view: 20.09.2019)].

2 Sam Dickson, Kilroy was here - mysterious WWII origins of the first viral graffiti meme, Dec 23, 2017 [https://www.thevintagenews.com/2017/12/23/kilroy-was-here-2/, (Last view: 20.09.2019)]. 
популярен, че противниците започват да вярват, че той е бил шпионин (Bates, 2014: p. 25).

Теорията за пьрвоизточника, която е най-убедителна и правдоподобна е на Ажеймс Килрой. Той е корабостроителен инспектор, като през Втората световна война работи в корабостроителница в Куинси, Масачузец (Quincy, Massachusetts). EAна от залачите му е $а$ следи за работата на работниците свьрзващи с нитове отАелните плочи по кораба. Тъй като налницата на работниците зависи от занитените нитове, те много често прибягват Ао измама като изтриват маркираните с тебешир белези за свършена работа и правят нови белези, с който си приписват работата на Аруг работник. Килрой намира решение на тази моша практика, като Аокато инспектира, поставя налпис „Килрой беше тук“ Ао всеки маркер на работник. СлеА завьршването на кораба някой от налписите остават, като по време на по Аръжката на кораба много хора от морския персонал срещат налписа. Тъй като Килрой проверява повечето места, в които привилно е няма^о никой преАи това, неговият налпис става като талисман за повечето войници в трудните времена на война.

Придружаващото налписа човече възниква благодарение на сътруаничеството межау съЮзническите сили. Много от страните си имат свой собствен Килрой. Австралийците имат Фу (Fоо), британците чал (Chad), някои от европейските нации имат Смо (Smoe), М. Пулина, Вася и т.н.

Можем да кажем, че този ранен пример за графоити, обиколил планетата, предхожАа с голини ерата на интернет сензациите или така наречените Анес миймове (memes).

Като цяло Аа оставиш името си/полписа си върху неща, които не ти приналлежат е вековна практика по цял свят. ЕАна от фрункциите на графритите е $\Delta а$ определят твоето присъствие. От изАраскването на Пирамидите Ао Анес, графритите не са нищо ново, те са Аьлбоко вплетени в човешката същност. СпореА Чаз Бохоркес Всички ние имаме изгарящо желание към буквите, думите и какво те ни казват. Те са жива форма на изкуството, разговор за живота (Hartl and Hundertmark, 2017 : p. 7). 


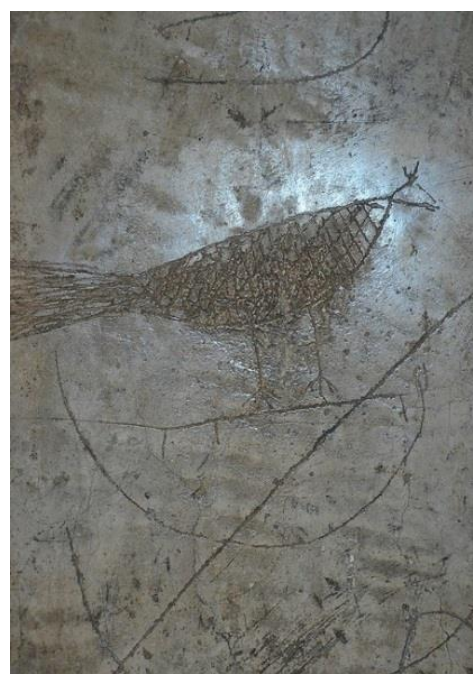

фигура 1. Помпей, графит на птица, фотография: Carole Raddato

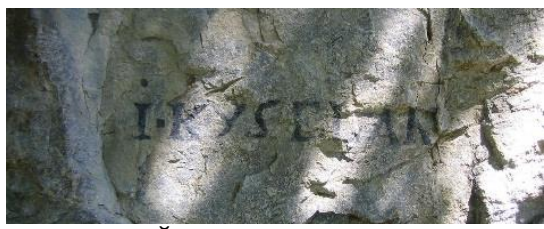

Фигура 3. Й. Киселак, Вахау, Австрия

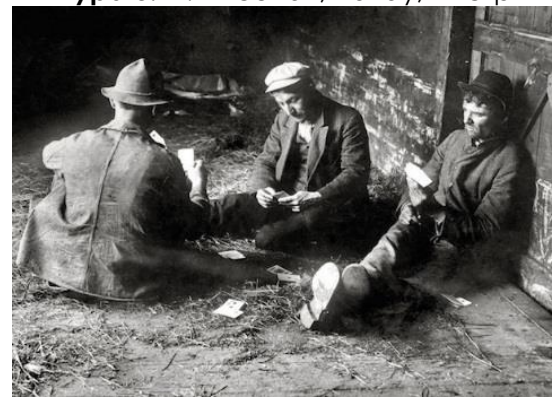

Фигура 5. Трима скитници играят карти, 1915, Колекция Бейн, Конгресна библиотека

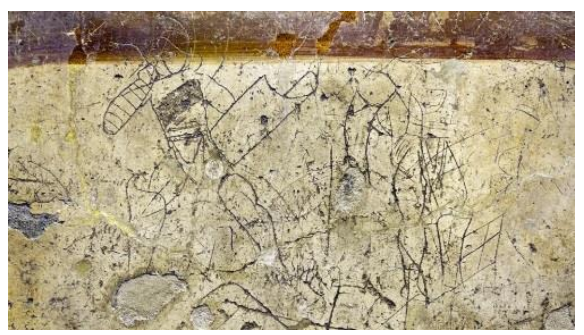

Фигура 2. Помпей, графиити изобразяващи глалиатори, национален археологически музей Неапол, фоотограффия: Darren Puttock

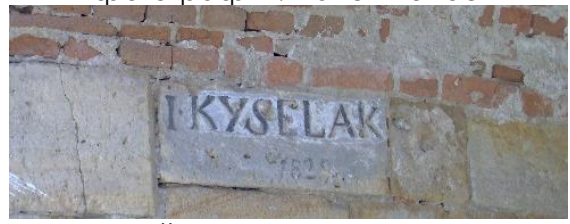

Фигура 4. Й. Киселак, Бърно, Чехия, 1829

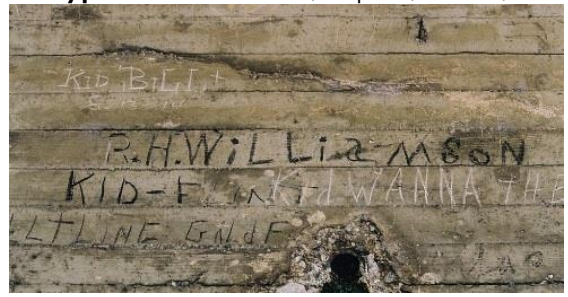

Фигура 6. Хобо налписи (Kid Bill, 1914), фротография Maria Margarita Lopez 


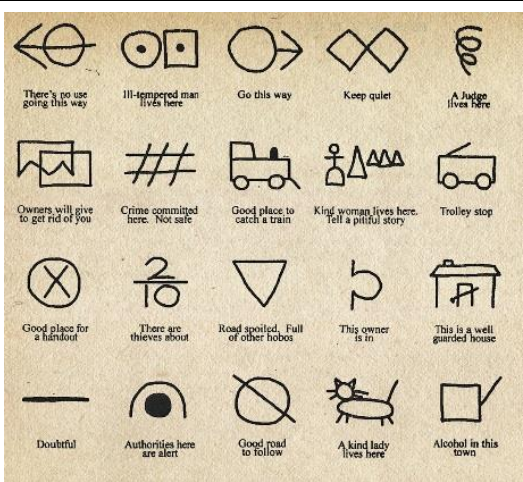

Фигура 7. Хобо знаци

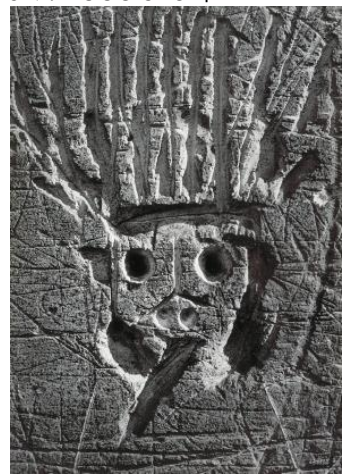

Фигура 9. Брасай, Кра^ят на с^ьнцето, графрити серия, 1944-1945

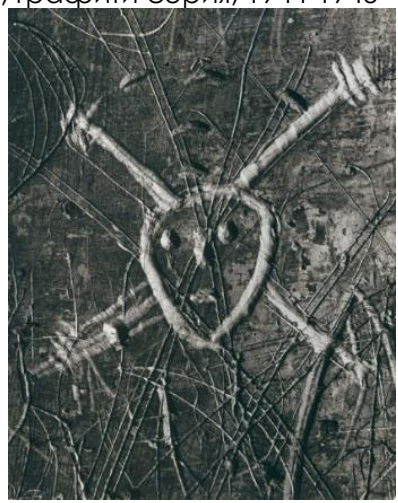

Фигура 11. Брасай, Смьртта, графити серия, 1930-1950

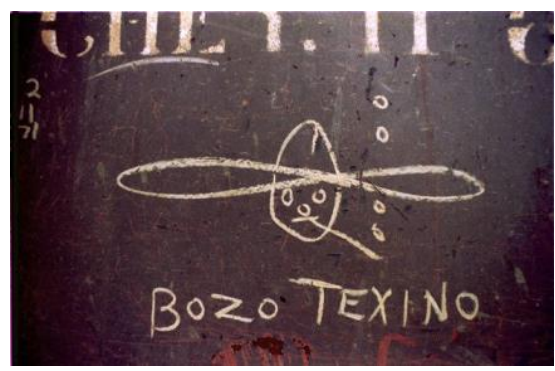

Фигура 8. Хобо налписи, Bozo Texino

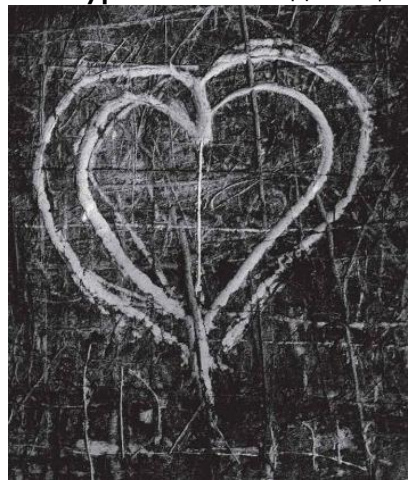

Фигура 10. Брасай, графрити серия, OKO^O 1950

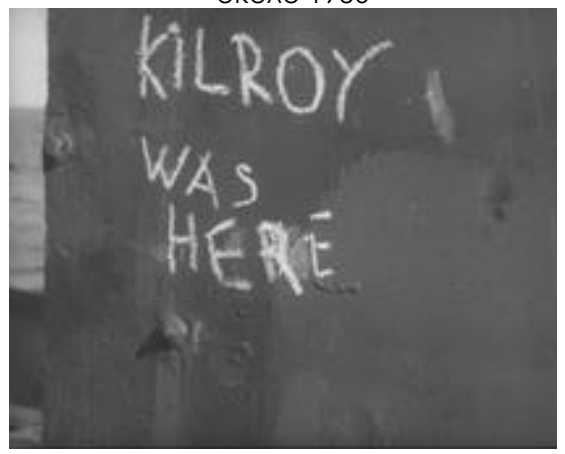

Фигура 12. Ки^рой беше тук, орилмови серии свьрзани с военни активности, Bikini Atoll, 1946 


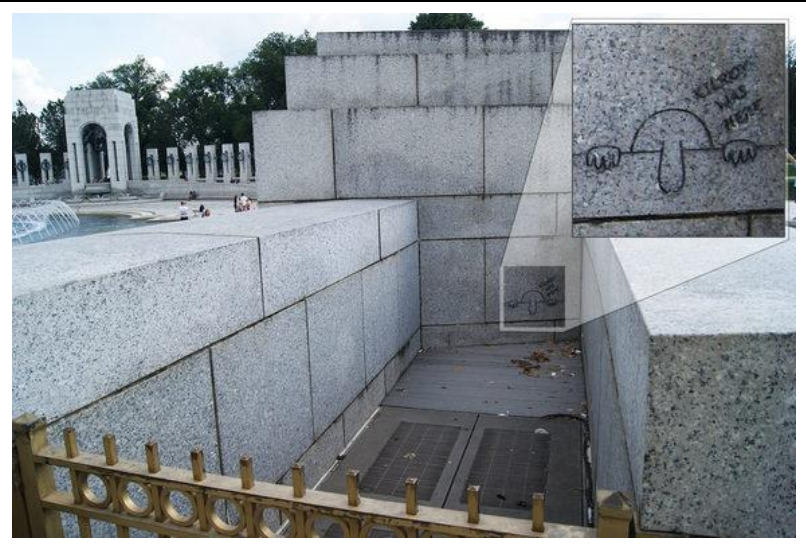

Фигура 13. Киярой беше тук, изобразен върху паметник

\section{Интернет източници / Internet sources:}

The saying 'Kilroy was here' - meaning and origin. [https://www.phrases.org.uk/meanings/kilroy-was-here.html, (Last view: 01.09.2019)]

Graffiti photographs by Brassaï V\&A Blog, [https://www.vam.ac.uk/blog/news/graffitiphotographs-by-brassai, (Last view: 01.09.2019)]

Graffiti, Brassaii, c.1950s | Tate, [https://www.tate.org.uk/art/artworks/brassai-graffitip80980, (Last view: 01.09.2019)]

Artazoi, [http://www.artazoi.com/expositions/circonstances-attenuantes, (Last view: 01.09.2019)]

"Kilroy Was Here"-A Story from World War II, [https://americacomesalive.com/2014/11/10/kilroy-story-world-war-ii, (Last view: 01.09.2019)]

Kilroy was here - mysterious WWII origins of the first viral graffiti meme, [https://www.thevintagenews.com/2017/12/23/kilroy-was-here-2, (Last view: 01.09.2019)]

The World War II meme that circled the world - YouTube, [https://www.youtube.com/watch?time continue=120\&v=AFw8MSF7yE4, (Last view: 01.09.2019)] 


\section{^итература / References}

Baird, J. A.; Taylor, Claire, (2016). Routledge Handbook of Graffiti and Street Art, 2016

Bates, Lindsay, (2014). Bombing tagging, writing : An analysis of the significance of graffiti and street art, Master's Thesis, University of Pennsylvania, Philadelphia, PA, 2014, 158 pages

Ganter, Chris, (2013). Graffiti School: A student guide, ISBN: 978-0-500-29097-2, Thames and Hudson, London, UK, 2013, 176 pages

Hartl, Patrik; Hundertmark, Christian, (2017). The art of writing your name: Contemporary Urban Calligraphy and beyond, ISBN: 978-3-939566-50-2, Publikat Publishing, Germany 2017, 256 pages

Lewisohn, Cedar, (2008). Street Art: The graffiti refolution, ISBN: 9781854378750 , Tate Gallery Publishing, London, UK, 2008, 160 pages

Lowndes, Coleman, (2018). The (mostly) true story of hobo graffiti, 2018

Milnor, Kristina, (2014). Graffiti And The Literary Landscape In Roman Pompeii, ISBN: 978-0-19-968461-8, Oxford University Press, USA, 2014, 336 pages

Ross, Jeffrey lan, (2016). Routledge Handbook of Graffiti and Street Art, ISBN: 978-1315-76166-4, Routledge Publishing, NY, USA, 2016, 520 pages 


\section{КУАТУРНО-ИСТОРИЧЕСКО НАСАЕАСТВО: \\ ОПАЗВАНЕ, ПРЕАСТАВЯНЕ, АИГИТААИЗАЦИЯ}

CULTURAL AND

HISTORICAL

HERITAGE

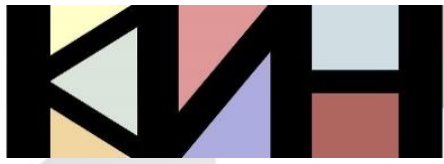

PRESERVATION PRESENTATION

DIGITIZATION
Материалите в сборника са обект на авторско право. Разрешава се безвъзмезАното ползване на техни електронни/ хартиени копия само за лична употреба или обучение, при пь^но цитиране на текущата страница и слеА писмена декларация от цитиращия за Аипса на търговски намерения. За копиране пол Аруга фрорма, препубликуване или публикуване на сървъри се изисква писмено разрешение и/или заплащане.

() Авторски колектив, 2019 Технически реАактори: Николай Ноев Калина Сотирова-Вълкова Ка^оян Николов

\section{Editors}

Galina Bogdanova Vanya Mateeva

This work is subject to copyright. Open and free of charge use of digital/hard copies of publications is granted only for personal or educational use, with full citation of the current page, and after written declaration of the quoting side for not-commercial Intention. For any other reproducing types, republishing, photocopying, recording, or any other storage retrieval system/ server written permission and/or fee is required.

(C) Authors` Group, 2019

Technical editors:

Nikolay Noev

Kalina Sotirova-Valkova

Kaloyan Nikolov

Научна поредица: том 5, брой 2 (7)/2019

Science series: vol. 5 , issue $2(7) / 2019$

www.math.bas.bg/vt/kin

ISSN: 2367-8038 